\title{
ASPEK RUANG PEMUKIMAN DI SISI SELATAN TEPI ALIRAN SUNGAI CENRANA, KABUPATEN BONE
}

\author{
Aspect of Settlements Space on the Southern Edge of the River \\ Flow Cenrana, District of Bone
}

\author{
Feby Wulandari \\ Alumni Jurusan Arkeologi, Universitas Hasanuddin \\ Jl. Perintis Kemerdekaan, km. 10, Makassar, Indonesia \\ moorningshine@gmail.com
}

Naskah diterima: 28/08/2017; direvisi: 19/10-30/11/2017; disetujui: 30/11/2017

Publikasi ejurnal: 12/12/2017

\begin{abstract}
Historical sources mention, Cenrana Site is a residential location of the Kingdom of Bone during the reign of La Patau Matanna Tikka. Archaeological research conducted earlier, mentioned that archaeological findings and environmental carrying capacity of this site gives an indication of the utilization aspect as the central government of the Kingdom of Bone. Although mentioning environmental conditions as one indication of aspects of site utilization, but the study does not analyze and explain contextually the environmental conditions referred. In the framework of filling the space, this study focuses on the analysis of archaeological environmental conditions located on the southern edge of the Cenrana River flow. The analysis used included community residence analysis in semi-micro scale. The results showed that the arrangement of residential space on the Cenrana Site extends from west to east. Meanwhile, the pattern of distribution of the findings is irregular and there are four divisions of space, namely: location of government, production location, residential location, and sacred location. The main factors affecting the division of space are the economic and environmental conditions that support, such as; geographical conditions, land characteristics, natural resources and accessibility.
\end{abstract}

Keyword: Settlement, Cenrana, spatial, environment.

Sumber-sumber sejarah menyebut, Situs Cenrana merupakan lokasi pemukiman Kerajaan Bone pada masa pemerintahan La Patau Matanna Tikka. Penelitian arkeologi yang dilakukan sebelumnya, menyebut bahwa temuan arkeologi dan daya dukung lingkungan situs ini memberi indikasi aspek pemanfaatan sebagai pusat pemerintahan Kerajaan Bone. Meski menyebut kondisi lingkungan sebagai salah satu indikasi aspek pemanfaatan situs, namun penelitian tersebut tidak menganalisis dan menjelaskan secara kontekstual kondisi lingkungan dimaksud. Dalam kerangka mengisi ruang tersebut, penelitian ini menitikberatkan pada analisis kondisi lingkungan tinggalan arkeologis yang berada di sisi selatan tepi aliran Sungai Cenrana. Analisis yang digunakan meliputi analisis pemukiman komunitas dalam skala semi-mikro. Hasil penelitian menunjukkan bahwa pengaturan ruang pemukiman di Situs Cenrana memanjang dari arah barat ke timur. Sementara, pola sebaran temuannya tidak beraturan dan terdapat empat pembagian ruang, yaitu: lokasi pemerintahan, lokasi produksi, lokasi pemukiman, dan lokasi sakral. Faktor utama yang mempengaruhi pembagian ruang tersebut yaitu ekonomi dan keadaan lingkungan yang mendukung, seperti; keadaan geografis, karakteristik lahan, sumberdaya alam dan aksesibilitas.

Kata Kunci: Pemukiman, Cenrana, keruangan, lingkungan. 


\section{PENDAHULUAN}

Catatan sejarah menunjukkan bahwa wilayah pemerintahan Kerajaan Bone yang berpusat di Cenrana telah memainkan peranannya dalam pembentukan sejarah budaya di Sulawesi Selatan. Hal ini, tidak lepas dari letak strategis Cenrana sebagai tempat untuk mengontrol zona-zona tepi danau besar di wilayah Sulawesi Selatan bagian tengah, dataran rendah Walennae, dataran timur dan pesisir sekitar Teluk Bone, Semenanjung Bira, Teluk Bantaeng, hingga ke Pulau Selayar. Pada awal perkembangannya, Cenrana merupakan bagian dari Kerajaan Luwu yang juga dikenal sebagai daerah penting di Sulawesi Selatan. Tahun 1520, Kerajaan Luwu mengalami kemunduran kekuasaan sehingga tidak mampu lagi untuk mempertahankan wilayah Cenrana dan akhirnya berhasil direbut oleh Kerajaan Bone (Andaya, 2004).

Penguasaan Bone atas Cenrana memberikan pengaruh yang cukup besar bagi masyarakat Bone dalam perkembangan sosial budaya, politik dan ekonomi, khususnya masyarakat di sekitar tepi aliran Sungai Cenrana. Sungai Cenrana yang berhulu dari Danau Tempe, mengalir mengikuti lembah sempit melalui bukit hingga bermuara ke laut di Teluk Bone memberikan peranan yang sangat penting dan strategis. Selain itu, peran aktivitas niaga mulai meningkat pada penguasaan Kerajaan Bone (Andaya, 2004:27).

Pada masa pemerintahan Arung Palakka tahun 1667-1696, Kerajaan Bone hendak membangun sebuah benteng di wilayah Cenrana. Arung Palakka kemudian meminta agar setiap penguasa berkontribusi dalam pembangunan benteng tersebut. Para penguasa akhirnya menyumbangkan tenaga kerja untuk pembangunan satu bagian benteng yang tinggi dindingnya 3,80 meter dan tebalnya $71 / 2$ meter di bagian dasarnya dan lebih 2 meter di bagian atasnya (Andaya, 2004: 310). Melihat perkembangannya, Arung Palakka awalnya berkeinginan untuk menjadikan Cenrana sebagai entrepot (penimbunan barang) dalam menyaingi Makassar sebagai pusat niaga terbesar di Sulawesi Selatan, namun hal ini tidak terwujud. Pada masa berikutnya, Raja Bone ke XVI La Patau Matanna Tikka menjadikan benteng ini sebagai tempat perlindungan bagi raja dan keturunan bangsawan lainnya, jika sewaktu waktu pusat kerajaan di Lalebata diserang. Dan pada perkembangan selanjutnya, oleh raja La Patau Matanna Tikka, Benteng Cenrana kemudian difungsikan sebagai pusat pemerintahan kedua setelah Lalebata.

Saat ini, di wilayah Cenrana tepatnya di sisi selatan tepi aliran sungai masih terdapat tinggalan budaya yang diidentifikasi sebagai pusat Kerajaan Bone di Cenrana. Lokasi ini pernah diteliti oleh Balai Arkeologi Makassar yang menemukan adanya indikasi pemukiman di lokasi tersebut. Data arkeologi yang ditemukan yaitu Situs Ujung Patue, Situs Benteng Laroe, Situs Pemukiman Botto, Situs Benteng Wajo, Pintu Gerbang Timuangnge, Benteng, Bekas Istana Bone Balla, Masjid Kuno, 7 buah Sumur, Tempat Pengolahan Mesiu, Tempat Pembakaran Kapur, Kompleks Makam Mapollo Bombang, Kompleks Makam Berinskripsi, Kompleks Makam Nisan Arca, Makam Syech Muhammad Jafar (Lapakkalosi), Kompleks Makam La Patau Matanna Tikka, Tempat Main Raga, Tempat Main Logo, dan Tempat Jemur Padi atau Allanrangnge. Aspek lain yang berhasil diungkap berdasarkan tinggalan budaya, letak strategis, dan kondisi lingkungannya. Situs Cenrana memberi indikasi aspek pemanfaatan yang lebih besar yaitu sebagai pusat pemerintahan Kerajaan Bone (Sarjiyanto, 2000: 69-73 dan 78).

Meski menyebut kondisi lingkungan sebagai salah satu indikasi aspek pemanfaatan situs, namun penelitian tersebut tidak menganalisis dan menjelaskan secara kontekstual kondisi lingkungan dimaksud. Dalam kerangka mengisi ruang tersebut, penelitian ini menitikberatkan pada 
analisis kondisi lingkungan tinggalan arkeologis yang berada di sisi selatan tepi aliran Sungai Cenrana. Dengan demikian, permasalahan yang dikaji dalam penelitian ini yaitu: bagaimana tata letak elemen elemen pemukiman di sisi selatan tepi aliran sungai Cenrana? dan bagaimana analisis kondisi lingkungan yang melatarbelakangi pembagian ruang pemukiman di situs Cenrana?

Mencermati permasalahan tersebut, maka tujuan yang ingin dicapai dalam penelitian ini adalah: mengetahui tata letak elemen-elemen pada pemukiman di sisi selatan tepi aliran Sungai Cenrana pada masa pemerintahan La Patau Matanna Tikka dan mengetahui faktor yang melatarbelakangi pembagian ruang di sisi selatan Sungai Cenrana.

Penelitian terdahulu terhadap Situs Cenrana menyebutkan situs ini memiliki indikasi pemukiman. Pemukiman merupakan suatu sistem produk dari interaksi variabel yang meliputi lingkungan alam, teknologi, sosial dan macam-macam institusi masyarakat dalam menghadapi kondisi variabel yang berbeda. Perbedaan inilah yang menyebabkan timbulnya perwujudan dari cara manusia atau masyarakat di dalam mengatur dirinya di muka bumi ini. Dengan demikian, pola-pola yang ada dalam pemukiman merefleksikan aspek-aspek budaya manusia, lingkungan alam dan gejala gejala geografisnya. Pemukiman mencakup tiga hal yang berkaitan dengan individu, komunitas dan pemukiman zonal (Anonim, 1999: 177).

Dalam konteks penelitian arkeologi, salah satu perspektif yang dapat digunakan untuk mengkaji situs pemukiman adalah berdasarkan aspek skala semi mikro. Pemukiman dengan skala semi mikro lebih luas sampai pada satu situs, dengan cakupan meliputi: jenis tinggalan, jalan, dan artefak non bangunan. Selain itu, penelitian ini juga diarahkan pada bangunan secara individual, hubungan antar bangunan, tata letak bangunan, posisi bangunan rumah tinggal terhadap bangunan publik dan makam (Anonim, 1999:177-178). Selain itu, skala semi mikro juga mempelajari sebaran dan hubungan lokasional dan artefak-artefak dan fitur-fitur dalam suatu situs (Mundardjito, 2002:4). Dalam hal ini, temuan arkeologi berupa bekas lokasi kegiatan yang terdiri atas keseluruhan situs dan bagian-bagiannya dipandang sebagai himpunan dari sejumlah kegiatan manusia masa lalu. Sekumpulan data yang diperoleh kemudian diinterpretasi untuk memperoleh gambaran tentang situs tersebut dan segala aspek yang dikandungnya (Hasanuddin, 2001: 12-13).

\section{METODE PENELITIAN}

Ruang lingkup penelitian ini meliputi keseluruhan data yang dapat memberi informasi terkait dengan periode okupasi di sisi selatan tepi aliran Sungai Cenrana. Oleh karena itu, penelitian ini diawali dengan pengumpulan data yang meliputi; studi pustaka yang mencakup sumber tertulis yang berkaitan dengan wilayah Cenrana; survei yang dilakukan yaitu melakukan penelusuran terhadap tinggalan budaya dan indikasi lain yang dapat memberikan informasi mengenai wilayah Cenrana; serta wawancara terbuka kepada orang orang yang dianggap mengetahui seluk beluk peninggalan kebudayaan masa raja La Patau Matanna Tikka.

Keseluruhan informasi yang diperoleh dalam tahap pengumpulan data akan dicatat secara sistematik mengenai hal hal yang akan diselidiki. Tahap berikutnya dilakukan pengolahan data, yang dititik beratkan pada wilayah pemukiman yang berada di sisi selatan tepi aliran Sungai Cenrana. Pada tahap ini juga dilakukan deskripsi dan identifikasi untuk kemudian melakukan pengklasifikasian temuan berdasarkan fungsi masing masing temuan. Terakhir, yaitu tahap penafsiran data. Tahap ini akan membuat tata letak pemukiman pada wilayah Cenrana dan menjelaskan faktor yang melatarbelakangi terjadinya pembagian ruang pemukiman di wilayah 
Cenrana. Dalam tahap penafsiran data, dilakukan pendekatan analogi sejarah untuk mendukung data arkeologi dalam upaya rekosntruksi sejarah budaya (Ambary, 1998: 151; Sharer and Ashmore, 1980).

\section{HASIL DAN PEMBAHASAN} 1. Profil Wilayah

Kabupaten Bone merupakan salah satu wilayah yang terdapat di Propinsi Sulawesi Selatan, tepatnya sekitar 174 kilometer sebelah timur Kota Makassar. Secara geografis Kabupaten Bone memiliki letak yang sangat strategis karena merupakan pintu gerbang pantai timur Sulawesi Selatan yang merupakan pantai barat Teluk Bone dengan panjang garis pantai 138 kilometer dari arah selatan ke arah utara. Kabupaten Bone terbagi atas 27 kecamatan yang mencakup Kecamatan Bonto Cani, Kahu, Kajuara, Salomekko, Tonra, Patimpeng, Libureng, Mare, Sibulue, Cina, Barebbo, Ponre, Lappariaja, Lamuru, Tellu Limpoe, Bengo, Ulaweng, Palakka, Awang Pone, Tellu Siattinge, Amali, Ajangale, Dua Boccoe, Cenrana, Tanete

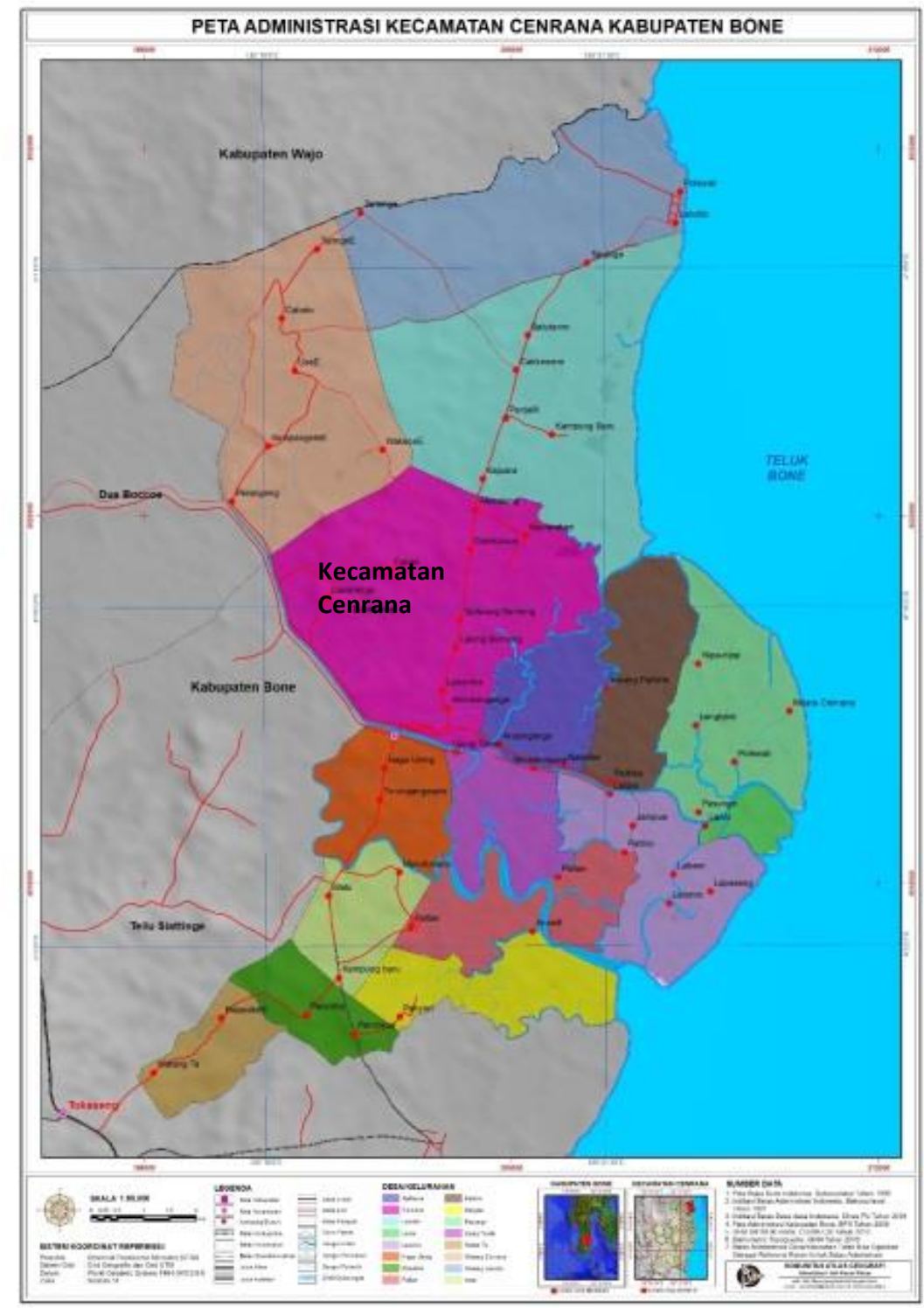

Gambar 1. Peta Administrasi Kecamatan Cenrana, Kabupaten Bone

(Sumber: pemda Kab. Bone, Tahun 2011) 
Riattang. Barat, Tanete Riattang, Tanete Riattang Timur, dengan luas wilayah Kabupaten Bone yaitu $4.556 \mathrm{~km}^{2}$ atau sekitar 7,3\% dari luas Propinsi Sulawesi Selatan. Secara astronomis Kabupaten Bone terletak antara posisi $4^{0} 13^{\prime}-5^{0} 06^{\prime} \mathrm{LS}$ dan antara $11^{\circ} 42^{\prime}-120^{\circ} 40^{\prime}$ BT (Ali, 1989).

Secara administratif Situs Cenrana berada di Kecamatan Cenrana, Kabupaten Bone. Kecamatan Cenrana merupakan salah satu dari 27 kecamatan yang ada di Kabupaten Bone dengan luas wilayah $143,60 \mathrm{~km}^{2}$ dan terbagi atas 15 desa. Kecamatan Cenrana terletak di posisi $4^{0} 19^{\prime} 49,5$ " LS dan $120^{\circ}$ 19'15,2" BT, dengan batas batas wilayah sebagai berikut: sebelah utara berbatasan dengan Kabupaten Wajo, sebelah selatan berbatasan dengan Kecamatan Tellu Siattinge, sebelah timur berbatasan dengan Teluk Bone dan sebelah barat berbatasan dengan Kecamatan Dua Boccoe (Ali, 1989).

Situs Cenrana terletak di dua desa yaitu Desa Nagauleng dan Desa Ujung Tanah. Dibandingkan dengan wilayah wilayah lain yang ada di Kabupaten Bone, umumnya wilayah Cenrana merupakan tanah datar yang berawa serta keadaan permukaan lahan yang landai dan sedikit bergelombang dengan kemiringan $0-15 \%$ (Anonim, 2006). Selain itu, jenis tanah di daerah ini adalah aluvial dan berada pada ketinggian 0-15 $\mathrm{m}$ dari permukaan laut sehingga wilayah ini lebih dominan ke area persawahan, rawa-rawa dan tambak, tetapi terdapat juga area permukiman penduduk dan perkebunan. Suhu udara di wilayah ini dikategorikan beriklim sedang atau subtropik yang berkisar antara $20^{\circ}-30^{\circ} \mathrm{C}$ dengan rata rata curah hujan berkisar antara 2000-2500mm. Mata pencaharian penduduk desa Nagauleng dan Ujung Tanah sebagian besar adalah petani persawahan, petani perkebunan cokelat dan pertambakan tetapi ada juga masyarakat yang memilih untuk bekerja di luar desa (Anonim, 2006).

\section{Sejarah Singkat Cenrana}

Nama Bone dahulunya disebut Tanah Bone, berdasarkan dari Lontara kata Bone berarti pasir yang dalam bahasa bugisnya berarti Kessi (pasir). Kerajaan Tanah Bone mulai terbentuk pada awal abad ke-XIV atau pada tahun 1330, tetapi sebelum Kerajaan Bone terbentuk kelompok kelompok dan pimpinannya dengan gelar kalula (Ali, 1984).

Kabupaten Bone merupakan kerajaan besar di Sulawesi Selatan sejak raja pertamanya ManurungngE Ri Matajang atau yang lebih dikenal dengan gelar Mata Silompo'e pada awal abad ke XIV (1330$1365 \mathrm{M})$. Adapun struktur pemerintahan kerajaan Bone dahulu meliputi:Arung Pone (Raja Bone), yang bergelar Mangkau. Makkedangnge Tanah, orang yang bertugas dalam bidang hubungan atau urusan dengan kerajaan lain (Menteri Luar Negeri). Tomarilaleng, yaitu orang yang bertugas dalam bidang urusan dalam daerah kerajaan lain (Menteri Dalam Negeri). Ade' Pitu (hadat Tujuh), terdiri dari tujuh orang yang merupakan pembantu utama atau pemimpin pemerintahan di Kerajaan Bone yaitu: Arung Ujung adalah orang yang bertugas mengepalai urusan penerangan Kerajaan Bone. Arung Ponceng, bertugas mengepalai urusan kepolisian atau kejaksaan dan pemerintahan. Arung $\mathrm{Ta}$ bertugas mengepalai urusan pendidikan dan mengetuai urusan perkara sipil. Arung Tibojong, yang bertugas mengepalai urusan perkara atau pengadilan Landschap atau badan besar yang mengawasi urusan perkara pengadilan Distrik atau badat kecil (sejenis polisi keamanan). Arung Tanete Riattang, bertugas mengepalai atau memegang kas kerajaan, mengatur pajak dan pengawasan keuangan. Arung Tanete Riawang, bertugas mengepalai bertugas mengepalai pekerjaan negeri (landschap werken-LW) pajak jalan dan pengawas Opzicher. Arung Macege, bertugas mengepalai urusan pemerintahan umum dan perekonomian (Rady, 2007:1516). 
Ponggawa (Panglima Perang), bertugas dibidang pertahanan kerajaan Bone dengan membawahi tiga perangkat yang masing masing: anreguru Anak Arung, bertugas mengkoordinir para anak bangsawan berjumlah 40 orang bertugas sebagai pasukan elit kerajaan. Pangulu Joa, bertugas mengkoordinir pasukan dari rakyat Tana Bone yang disebut passiuno artinya: pasukan siap tempur di medan perang setiap saat, rela mengorbankan jiwa raganya demi tegaknya Kerajaan Bone dari gangguan kerajaan lain.

Dulung (Panglima Daerah), bertugas mengkoordinir daerah kerajaan bawahan, di kerajaan Bone terdapat dua dulung, yakni: Dulungna Ajangale dari kawasan Bone Utara dan Dulungna Awang Tangka dari Bone Selatan. Jennang (Pengawas), berfungsi mengawasi para petugas yang menangani bidang pengawasan baik dalam lingkungan istana maupun dengan daerah atau kerajaan bawahan.

Kadhi (Ulama), merupakan perangkat yang terdiri dari Imam, Khatib, Bilal dan lain lain. Kadhi bertugas sebagai penghulu syara dalam bidang agama islam. Keberadaan kadhi di kerajaan bone ini senantiasa bekerja sama demi kemaslahatan rakyat bahkan raja Bone meminta fatwa kepada kadhi khususnya menyangkut hukum Islam. Bissu (waria), bertugas untuk merawat benda benda kerajaan, disamping melaksanakan pengobatan tradisional, bissu juga bertugas dalam hal kepercayaan kepada Dewata SeuwaE, tetapi setelah masuknya agama Islam di Kerajaan Bone bissu tidak diaktifkan lagi.

Sebelum Kolonial Belanda berkuasa dan Bone masih berbentuk kerajaan, wilayah $\mathrm{Ta}$ dahulunya merupakan kerajaan kecil yang bernaung di bawah kerajaan Bone. Arung Ta merupakan salah satu dari dewan Ade' Pitu di kerajaan Bone. Ade' Pitu merupakan pembantu utama atau pemimpin pemerintahan di Kerajaan Bone yang terdiri dari 7 pejabat, di mana Arung Ujung sebagai ketua dewan yang disebut To Marilaleng, lalu Arung Ponceng, Arung Ta, Arung Macege, Arung Tanete Riattang, Arung Tanete Riawa dan Arung Tibojong.

Wilayah Cenrana pernah menjadi pusat kota perdagangan pada zaman Kerajaan Bone pada masa pemerintahan Raja Bone ke XVI yaitu La Patau Matanna Tikka tepatnya di desa Nagauleng. Penempatan Cenrana sebagai wilayah perdagangan didukung dengan adanya aliran sungai Cenrana yang memberikan jalan untuk melakukan perdagangan hingga ke wilayah pedalaman seperti Wajo. Selain itu, Desa Nagauleng juga dijadikan tempat peristirahatan La Patau Matanna Tikka. Desa Nagauleng juga sebagai penghasil pangan dan kapur untuk di bawa ke kerajaan Bone sehingga keberadaan wilayah Cenrana dapat dikatakan memiliki peranan yang cukup penting bagi kerajaan Bone (Sarjiyanto, 2000).

\section{Deskripsi Situs Cenrana}

Secara administratif situs Cenrana terletak di dua desa yaitu Desa Nagauleng dan Desa Ujung Tanah. Dua desa tersebut berada di Kelurahan Cenrana, Kecamatan Cenrana Kabupaten Bone, untuk menuju ke lokasi penelitian ini dapat ditempuh dengan kendaraan roda dua sejauh 38 kilometer dari Kota Watampone. Situs Cenrana dikelilingi oleh aliran sungai, di mana pada sisi utara terdapat Sungai Cenrana, di sisi selatan terdapat Sungai Watu, sisi timur terdapat Sungai Laopo dan di sisi barat terdapat Sungai Palakka yang merupakan sungai buatan sehingga sebagian besar sungai Cenrana merupakan dataran rendah dan hanya sisi barat laut yang merupakan dataran tinggi. Sebagian besar penduduk yang hidup di sekitar Situs Cenrana bermata pencaharian sebagai petani kebun, sawah dan tambak tetapi ada juga masyarakat yang bekerja di bidang pemerintahan.

Wilayah Cenrana sangat subur akan hasil buminya. Hasil bumi Cenrana yang utama yaitu padi dan tambak. Selain itu, di 
wilayah Cenrana juga memiliki kandungan air yang cukup tawar tetapi hanya sebagian yang difungsikan. Sumur sumur tersebut dijadikan sumber air bersih karena pada umumnya wilayah Cenrana memiliki kandungan air yang tidak layak dikonsumsi. Pada situs Cenrana terdapat beberapa tinggalan budaya, meliputi:

\section{a. Benteng dan Pintu Gerbang Timuangnge}

Benteng yang ada pada situs pemukiman di Cenrana berada di sisi barat dari lokasi bekas istana. Keberadaan benteng ini selain difungsikan sebagai batas wilayah, juga sebagai benteng pertahanan jika sewaktu waktu Wajo menyerang dari arah barat, mengingat sebagian besar wilayah Cenrana di kelilingi oleh sungai-sungai besar seperti Sungai Watu di sisi timur dan selatan serta Sungai Cenrana di sisi utara. Benteng ini memanjang dari arah utara ke arah selatan dan pada bagian tengahnya terdapat sebuah pintu gerbang. Berdasarkan pengamatan yang dilakukan, dinding benteng ini lebih banyak memanfaatkan kondisi tanah yang tinggi dan hanya sebagian saja dinding benteng yang terbuat dari batuan kapur yang telah diberi perekat. Struktur dinding batu ini berukuran panjang 12 meter dari pintu gerbang. Benteng ini berukuran panjang 50 meter ke arah utara dari pintu gerbang.

Situs Cenrana hanya memiliki sebuah pintu gerbang yang berada di sebelah barat desa Nagauleng, masyarakat menyebutnya dengan sebutan Timuangnge. Pintu gerbang ini terbuat dari susunan batu yang direkatkan. Bahan batu yang digunakan dalam pembuatannya khusus didatangkan dari daerah Mampu. Bentuk pintu masih dapat terlihat dengan jelas. Orientasi pintu gerbang menghadap TimurBarat.

\section{b. Lokasi Permainan Marraga}

Marraga atau mandaga berasal dari bahasa Bugis yang dalam bahasa Indonesia dikenal dengan sepak raga. Lapangan ini dulunya masuk dalam wilayah Kampung Palakka. Lokasi permainan ini terletak tidak jauh dari pintu gerbang Timungange, tepatnya di sisi selatan pintu gerbang. Lahannya berukuran \pm 30 meter. Lokasi ini telah di tumbuhi semak belukar.

\section{c. Lokasi Permainan Mallogo}

Penamaannya bersumber dari nama peralatan permainan Logo yang berbentuk menyerupai cangkul. Bentuknya yang seperti cangkul mencerminkan nilai budaya bugis yang berdasar pada kehidupan agraris. Permainan ini biasanya dilakukan sesudah panen dan juga pada waktu senggang. Logo terbuat dari tempurung kelapa yang berkualitas baik dan berbentuk segitiga yang ujung-ujungnya ditumpulkan. Lokasi permainan mallogo berbatasan langsung dengan lokasi permainan marraga, yaitu terletak di sisi timur lapangan marraga. Lebar lahan mallogo 5 meter dan panjangnya 50 meter dengan kondisi tanahnya tidak datar dan lapang.

\section{d. Lokasi Bekas Istana Bone Balla}

Lokasi bekas istana berada di dalam wilayah Kampung Mojong dan lokasinya cukup tinggi. Menurut informasi luas lokasi bekas istana berukuran kurang lebih 60 meter persegi. Menurut cerita, pernah ada bangunan yang disebut Bone Balla oleh masyarakat. Menurut informasi juga bangunannya menghadap ke timur. Lokasi bekas istana ini sekarang dijadikan perkebunan coklat. Di sekitar lokasi ini terdapat banyak fragmen gerabah dan keramik asing, hal ini menandakan dulunya pernah terdapat pemukiman dan aktivitas manusia di lahan ini.

\section{e. Lokasi Masjid Tua}

Lokasi Masjid Tua Cenrana berada di kampung Cenrana. Masjid ini merupakan masjid pertama yang dibangun di wilayah Cenrana. Lokasi masjid berbatasan langsung dengan Sungai Cenrana pada bagian utara 
masjid. Bangunan ini berbentuk persegi empat dan tidak permanen serta tidak memiliki dinding dengan atap yang terbuat dari daun nipa. Lokasi masjid berukuran panjang 50 meter dan lebar 32 meter.

\section{f. Sumur Tua}

Situs Cenrana terdapat juga tujuh sumur tua. Ketujuh sumur ini mengidentifikasikan bahwa dahulu pernah ada permukiman di wilayah ini. Menurut informan, ketujuh sumur ini di sebut Baba Pitu'e (tujuh sumur). Ketujuh sumur ini memiliki ukuran dan bentuk yang sama tetapi ketujuh sumur ini tidak semua memiliki konstruksi bangunan permanen untuk melindungi mulut sumur. Sumursumur ini juga memiliki fungsi yang berbeda-beda. Sumur I, dulunya di fungsikan sebagai tempat berwudhu tetapi sekarang tidak difungsikan lagi. Sumur II, dulunya difungsikan sebagai tempat mencuci pakaian dan peralatan makan tetapi sekarang tidak difungsikan lagi. Sumur III, dulunya di fungsikan sebagai tempat pencuci beras, sekarang difungsikan penduduk sebagai sumber air bersih. Sumur IV, dulunya sumur ini difungsikan sebagai tempat minum kuda dan sekarang dimanfaatkan penduduk setempat sebagai sumber air bersih. Sumur V, sumur ini hingga sekarang masih dimanfaatkan penduduk sebagai sumber air bersih. Sumur VI, sumur ini juga masih difungsikan penduduk sebagai sumber air bersih. Sumur VII, dulunya difungsikan sebagai tempat mencuci kaki tetapi sekarang dimanfaatkan penduduk sebagai sumber air bersih.

\section{g. Tempat Pembakaran Kapur}

Lokasi pembakaran kapur berada di Kampung Palakka. Di lokasi pembakaran kapur terdapat tiga buah tungku yang berjejer dari arah selatan ke utara. Tungku pembakaran berbentuk menyerupai sumur yang mana semakin ke bawah maka ukuran diameternya semakin kecil. Ukuran tungku pun berbeda beda. Kondisi tungku masih terlihat baik dan utuh, terlihat pada bentuk lubang pintu untuk memasukkan kayu bakar mirip kubah masjid atau berbentuk setengah lingkaran.

\section{h. Lokasi Bekas Penjemuran Kapur}

Lokasi pembakaran kapur berada di Kampung Palakka. Di lokasi pembakaran kapur terdapat tiga buah tungku yang berjejer dari arah selatan ke utara. Tungku pembakaran berbentuk menyerupai sumur yang mana semakin ke bawah maka ukuran diameternya semakin kecil. Ukuran tungku pun berbeda-beda. Kondisi tungku masih terlihat baik dan utuh, terlihat pada bentuk lubang pintu untuk memasukkan kayu bakar mirip kubah masjid atau berbentuk setengah lingkaran.

\section{i. Pemakaman Tua di Situs Cenrana}

Pemakaman tua di Situs Cenrana, memiliki empat kompleks, yaitu: pertama, Kompleks Makam Raja La Patau Matanna Tikka berada di jalan poros Watu dan dekat dengan pemukiman. Pintu masuk kompleks makam berada di sisi selatan dan barat makam. Bagian dalam kompleks makam terdapat bangunan yang digunakan sebagai tempat penyimpanan alat-alat peninggalan raja La Patau Matanna Tikka seperti tombak, bendera dan baskom perunggu yang digunakan sebagai tempat membasuh kakinya. Bangunan kompleks makam berbentuk persegi panjang (Makmur, 1997). Adapun beberapa makam yang terdapat dalam kompleks makam raja ini yaitu: Makam Raja La Patau Matanna Tikka. Makam istri pertama La Patau Matanna Tikka. Makam istri kedua La Patau Matanna Tikka. Makam istri ketiga La Patau Matanna Tikka. Makam istri keempat La Patau Matanna Tikka. Makam istri kelima La Patau Matanna Tikka. Makam Buto. Makam Mattejo (Ulama Fikih). Makam 1 (makam kecil). Makam Petta Janggoe (pemimpin pasukan). Makam Pettarala (Passeppi). Makam Petta Macalla (Paccilo-Cilo). Makam dengan tipe nisan Gada. Makam 2 
(tidak memiliki nama). Makam dengan jirat yang panjang.

Kedua, Makam mappolo bombing terletak di sisi selatan dari lokasi bekas istana Bone Balla, tepatnya di Kampung Kalokkoe. Makam ini merupakan makam ibunda raja La Patau Matanna Tikka. Lokasi ini sekarang hampir tidak terlihat karena telah tertutupi semak belukar. Pada lokasi ini banyak terlihat makam yang sudah tidak terawat tetapi makam Mappolo Bombang masih terlihat dengan kondisi yang baik.

Ketiga, Kompleks makam ini berada dalam perkebunan cokelat penduduk, tepatnya di sisi utara lokasi peleburan mesiu. Menurut informan makam ini merupakan makam tua di wilayah Cenrana. Kompleks makam ini hampir tidak dapat diidentifikasi keberadaannya karena umumnya makam yang ada sudah tidak memiliki jirat dan telah tertimbun oleh ranting serta dedaunan yang telah kering. Di kompleks makam ini terdapat beberapa jenis nisan salah satunya nisan yang berbentuk arca.

Keempat, kompleks makam ini berada dalam perkebunan cokelat penduduk. Menurut informan, makam ini merupakan kompleks makam orang-orang Wajo yang meninggal karena ingin merebut dan menguasai wilayah Cenrana.

\section{j. Parit}

Lokasi parit terletak tidak jauh dari lokasi bekas istana Bone Balla dan lokasi peleburan mesiu. Parit ini dibuat melintang dari arah barat (sungai Palakka) ke arah timur (lokasi bekas istana Bone Balla) dengan lebar parit 3 meter. Menurut informan, parit ini difungsikan sebagai pengairan ke istana dan juga sebagai jalur pengangkutan dari Sungai Palakka ke istana dengan menggunakan perahu kecil (sampan).

\section{k. Lokasi Peleburan Mesiu}

Lokasi peleburan mesiu berada di sisi barat lokasi bekas Istana Bone Balla. Pada penelitian sebelumnya mengatakan bahwa lokasi ini merupakan lokasi peleburan mesiu dan terdapat lempengan batu besar dimana batu tersebut merupakan batu untuk penahan panas (Sarjiyanto, 2000).

\section{Fragmen Keramik dan Gerabah}

Sebaran fragmen gerabah dan keramik yang ditemukan di beberapa lokasi dalam situs Cenrana menunjukkan bahwa lokasi tersebut pernah ada aktivitas manusia. Lokasi yang dominan ditemukan fragmen gerabah dan keramik berada di lokasi bekas Istana Bone Balla, lokasi pembakaran kapur dan lokasi pemakaman orang-orang Wajo. Ketiga lokasi ini ditemukan 97 buah fragmen keramik dan 23 fragmen gerabah.

\section{Gambaran Pemukiman Cenrana}

Pemukiman atau lokasi kediaman pemerintahan raja La Patau Matanna Tikka merupakan wilayah pilihan yang dipakai untuk pemukiman raja La Patau Matanna Tikka. Memahami struktur ruang lingkup kediaman pemerintahan raja La Patau Matanna Tikka di wilayah Cenrana maka kita harus melihat dari sisi budaya, tingkah laku dan teknologinya.

Lokasi kediaman pemerintahan $L a$ Patau Matanna Tikka terletak di sekitar atau dalam lingkungan Cenrana yang pada umumnya berada di tepi aliran Sungai Cenrana. Keletakan bangunan fasilitas pemerintahan masa pemerintahan raja $L a$ Patau Matanna Tikka berada di bagian selatan tepi aliran Sungai Cenrana.

Menurut hasil pendataan, pemukiman pemerintahan raja La Patau Matanna Tikka di Kecamatan Cenrana Kabupaten Bone menyebar ke seluruh wilayah Cenrana tetapi bekas lokasi dan bangunan masa pemerintahan raja La Patau Matanna Tikka tidak merata dan sebagian besar bekas lokasi dan bangunan masa pemerintahan raja La Patau Matanna Tikka berpusat pada wilayah selatan tepi aliran sungai Cenrana. Adapun bekas lokasi dan bangunan masa pemerintahan raja La Patau 


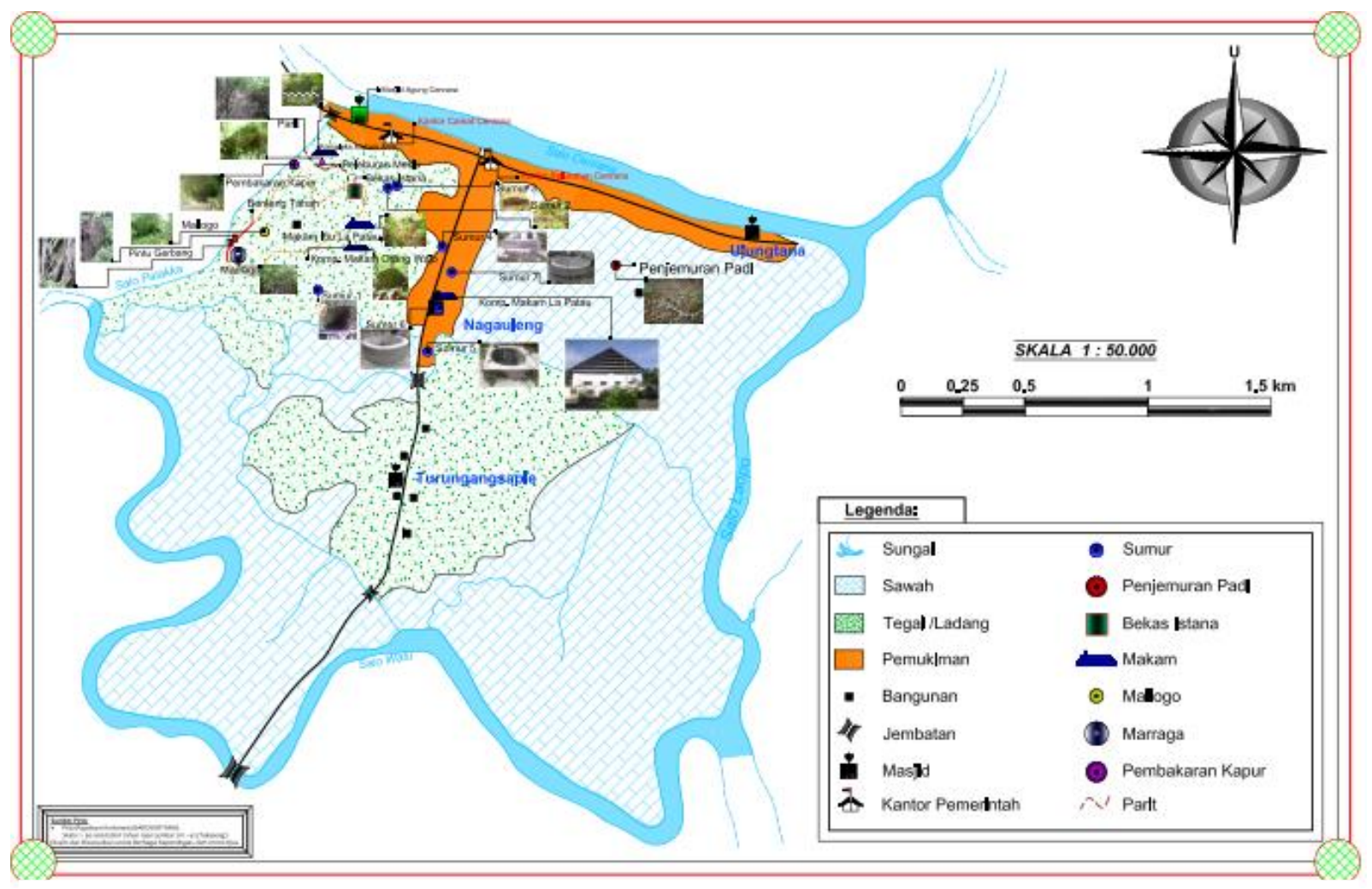

Gambar 2. Peta Sebaran Temuan Tepi Aliran Sungai Cenrana

(Sumber: Dokumentasi pribadi Febi Wulandari, Tahun 2011)

Matanna Tikka, yaitu: Bekas Lokasi Istana Bone Balla, Kompleks Makam Arca, Lokasi Masjid Tua Cenrana, Parit Buatan, Lokasi Peleburan Mesiu, Lokasi Pembakaran Kapur, Benteng Tanah, Lokasi Penjemuran Padi, Lokasi Pertemuan raja $L a$ Patau Matanna Tikka (Mallogo dan Marraga), Pintu Gerbang, Makam Ibunda raja La Patau Matanna Tikka, Kompleks Makam Orang Wajo, Kompleks Makam raja La Patau Matanna Tikka, Sumur 1, Sumur 2, Sumur 3, Sumur 4, Sumur 5, Sumur 6 dan Sumur 7.

Setiap keletakan bekas lokasi dan bangunan masa pemerintahan raja La Patau Matanna Tikka memiliki jarak yang berjauhan sehingga membutuhkan sarana transportasi. Fasilitas infrastruktur pemukiman di wilayah Cenrana, yaitu: jaringan jalan, pelabuhan, tempat perdagangan dan tempat bermukim. Jaringan jalan yang dibuat untuk kepentingan masyarakat agar dapat memudahkan masyarakat dalam melakukan aktivitasnya. Pembuatan pelabuhan dan tempat berdagang atau pasar juga dibuat untuk memudahkan masyarakat dalam pemenuhan kebutuhan hidupnya.

\section{Pembagian Ruang Situs Cenrana dan Faktor Lingkungannya \\ Wilayah Cenrana merupakan salah} satu daerah yang memiliki peran penting dalam pemerintahan Kerajaan Bone. Tata letak pemukiman pada situs Cenrana didasari atas sebaran tinggalan arkeologi yang menjadi bukti kegiatan manusia masa lampau dan kemudian dapat dijadikan sumber data untuk mengetahui aktivitas mereka.

Alasan penentuan letak dari masing masing pembagian ruang dikarenakan wilayah Cenrana memiliki ketinggian 0-25 meter di atas permukaan air laut. Wilayah Cenrana merupakan wilayah yang strategis karena dikelilingi jalur transportasi antar daerah sehingga memudahkan dalam aspek pertahanan wilayah. Faktor yang 
mempengaruhi pembagian ruang di wilayah Cenrana Kabupaten Bone, yaitu: keadaan lingkungan. Keadaan lingkungan dalam pemilihan lokasi pemukiman masa pemerintahan raja La Patau Matanna Tikka mencakup pertimbangan, seperti: keadaan geografis, karakteristik lahan, sumberdaya alam dan aksesibilitas.

Pemilihan lokasi dipengaruhi oleh keadaan fisik lingkungan. Wilayah Cenrana pada bagian sisi selatan tepi aliran sungai Cenrana sangat strategis karena berbatasan langsung dengan sungai-sungai yang dapat dijadikan sebagai jalur transportasi sekaligus pertahanan wilayah pemerintahan raja $L a$ Patau Matanna Tikka.

Penggunaan lahan adalah pembagian lahan berdasarkan sumberdaya alam dan potensi yang dapat diperoleh dari wilayah tersebut. Pembagian tersebut mencakup empat arah mata angin, yaitu: timur, barat, utara dan selatan. Pembagian ini diperuntukkan untuk meningkatkan perekonomian penduduk dan pembagian lahan juga diperuntukkan agar tidak menimbulkan perpecahan pada penduduk setempat.

Wilayah Cenrana merupakan sebuah delta (menyerupai sebuah pulau) karena berada di dalam satu daratan dan terpisah oleh beberapa sungai yang mengelilinginya, seperti; Sungai Cenrana, Sungai Watu, Sungai Salokae, Sungai Pallima, Sungai Tua' Cenning, Sungai Cekkong dan Sungai Attampatu.

Pembagian ruang yang berdasarkan empat arah mata angin, telah menentukan satu posisi yang dijadikan titik tumpu atau datum point agar memudahkan pembagian ruang di wilayah Cenrana. Adapun titik tumpu yang dijadikan patokan, yaitu: Lokasi Bekas Istana Bone Balla. Pembagian ruang di wilayah ini, di antaranya: di utara terdapat tinggalan: Kompleks Makam Arca dan Lokasi masjid tua Cenrana. Pada bagian barat terdapat tinggalan; Parit Buatan, Lokasi Peleburan Mesiu, Lokasi Pembakaran Kapur, Lokasi Benteng Tanah,
Tempat Pertemuan (Mallogo dan Marraga), Pintu Gerbang, Sungai Buatan (Sungai Palakka). Pada sisi selatan terdapat tinggalan: Makam Ibunda raja La Patau Matanna Tikka, Kompleks Makam Orang Wajo, dan Sumur 1. Pada sisi timur terdapat tinggalan: Sumur 2, Sumur 3, Sumur 4, Sumur 5, Sumur 6, Sumur 7, Kompleks Makam Raja La Patau Matanna Tikka dan Lokasi Penjemuran Padi.

Kondisi lingkungannya di bagian barat lokasi Bekas Istana Bone Balla memperlihatkan wilayah yang berbukit dan berawa. Pada bagian utara Istana Bone Balla memperlihatkan kondisi lingkungan yang rendah, bergelombang dan sebagian wilayahnya dekat tepi aliran Sungai Cenrana yang terlihat datar. Pada bagian timur, memperlihatkan daratan yang rendah, datar tetapi sebagian wilayahnya yang lain berawa. Sedangkan bagian selatan memperlihatkan wilayah yang bergelombang dan berawa.

Penataan ruang di wilayah Cenrana terbagi atas beberapa fungsi, seperti: Lokasi Pemerintahan, Lokasi Produksi, Lokasi Pemukiman, dan Lokasi Sakral. Adapun penjabaran dari masing masing fungsi lokasi, meliputi empat lokasi, yaitu:

\section{a. Lokasi Pemerintahan}

Lokasi pemerintahan yang dimaksud, yaitu; lokasi Bekas Istana Bone Balla, lokasi Pertemuan Raja (Mallogo dan Marraga), lokasi Benteng Tanah, Pintu Gerbang. Keberadaan temuan tersebut menyebar ke bagian utara dan barat. Wilayah Cenrana, pada bagian utara terdapat aliran Sungai Cenrana yang dapat dijadikan lokasi pelabuhan, tempat berkomunikasi dan tempat pertahanan. Ketiga hal di atas menjadi alasan untuk membangun Istana Bone Balla di bagian utara dengan maksud dapat mengontrol keamanan wilayah Cenrana. sedangkan pada lokasi pertemuan (Mallogo dan Marraga), Lokasi Benteng Tanah dan Pintu Gerbang di bagian barat Istana Bone Balla dikarenakan lokasi pada 
bagian barat cukup tinggi sehingga dapat dijadikan tempat pertahanan dan lokasi pertemuan raja yang memiliki kebiasaan bermain mallogo dan marraga.

\section{b. Lokasi Produksi}

Lokasi produksi yang dimaksud, yaitu; Lokasi Penjemuran Padi, Lokasi Pembakaran Kapur, Lokasi Peleburan Mesiu. Masa pemerintahan raja La Patau Matanna Tikka memusatkan produksinya pada sektor pertanian, pembuatan senjata dan bahan perekat dikarenakan wilayah Cenrana memiliki ketersediaan lahan yang produktif terhadap pertanian, senjata dan bahan perekat.

Wilayah produksi pertanian terletak di bagian barat, timur dan selatan Lokasi Istana Bone Balla, hal ini terbukti dengan ditemukannya Lokasi Penjemuran Padi (Allarangge) yang berada di bagian timur Istana Bone Balla tepatnya di tengah tengah persawahan penduduk. Lantai jemur ini berfungsi sebagai lokasi penjemuran hasil pertanian khususnya padi. Padi-padi yang telah dikeringkan akan dikirim ke pusat pemerintahan di Lalebata sebagai hasil pertanian kerajaan. Lokasi pertanian difokuskan pada wilayah timur dan selatan dikarenakan kondisi lingkungannya yang rendah dan berawah sehingga memudahkan distribusi air yang vital bagi lahan pertanian.

Lokasi Pembakaran Kapur dan Peleburan Mesiu terletak di bagian barat Istana Bone Balla. Keberadaan lokasi pembakaran kapur yang terletak di pinggir aliran Sungai Palakka menunjukkan adanya hubungan antara Sungai Palakka dengan tempat pembakaran kapur. Keletakan ini dimaksudkan untuk memudahkan pengangkutan batu kapur atau koral-koral yang berasal dari laut menuju lokasi pembakaran tersebut yang kemudian diolah menjadi bahan perekat. Keberadaan sungai buatan (Sungai Palakka) selain diperuntukkan untuk jalur pengangkutan juga difungsikan sebagai sumber air selama kegiatan produksi bahan perekat berlangsung.

Sedangkan Lokasi Peleburan Mesiu diperuntukkan untuk pembuatan senjata masa pemerintahan Raja La Patau Matanna Tikka. Pada Lokasi Peleburan Mesiu juga ditemukan sebuah parit yang difungsikan sebagai jalur pengangkut menuju Istana Bone Balla dan sebagai sumber air terdekat untuk mendinginkan senjata yang telah ditempa.

Lokasi Pembakaran Kapur dan Peleburan Mesiu di bagian barat Istana Bone Balla dikarenakan kondisi lingkungannya yang berbukit dan bergelombang sehingga memudahkan pembuatan tungku pada pembakaran kapur dan pembuatan lubang peleburan mesiu.

\section{c. Lokasi Pemukiman}

Lokasi pemukiman yang dimaksud, yaitu: Lokasi Pemakaman Ibunda Raja $L a$ Patau Matanna Tikka, Kompleks Makam Raja La Patau Matanna Tikka, Kompleks Makam Orang Wajo, Kompleks Makam Arca, Sumur 1, Sumur 2, Sumur 3, Sumur 4, Sumur 5, Sumur 6, Sumur 7, Parit dan Sungai Buatan (Palakka).

Wilayah Cenrana sebagian besar merupakan daerah berawa dan dataran banjir sehingga sulit memperoleh air bersih. Pemukiman pemerintahan raja La Patau Matanna Tikka telah membangun beberapa sumur yang telah menyebar di bagian timur dan selatan Istana Bone Balla. Sumur-sumur yang dibangun difungsikan untuk keperluan penduduk setempat. Keletakan sumur di bagian timur dan selatan Istana Bone Balla dikarenakan wilayahnya yang datar dan sedikit bergelombang sehingga penduduk dapat memanfaatkannya untuk bermukim.

Pada wilayah Cenrana ditemukan pula beberapa lokasi pemakaman yang menjadi indikasi pemukiman, yaitu: Kompleks Makam Raja La Patau Matanna Tikka berada di bagian timur Istana Bone Balla dikarenakan wilayah pada bagian timur dominan rendah dan datar serta dapat 
diakses dengan cepat sebab tersedia jalur transportasi. Kompleks makam orang Wajo berada di bagian selatan Istana Bone Balla. Wilayah di bagian selatan juga memperlihatkan daratan rendah dan cukup datar. Makam ibunda Raja La Patau Matanna Tikka yang dijuluki Mappolo Bombang juga berada di bagian selatan Istana Bone Balla.

Pemukiman di wilayah Cenrana memiliki bentang alam yang strategis sebagai sarana perlindungan dari serangan musuh. Wilayah pemerintahan raja La Patau Matanna Tikka dikelilingi oleh sungaisungai besar, yaitu: Sungai Watu di bagian timur, Sungai Laopo di selatan, Sungai Cenrana di utara dan Sungai Palakka di barat. Keberadaan sungai tersebut memberikan keuntungan tersendiri bagi pemerintahan Cenrana dalam hal pertahanan wilayah.

Bagian barat Istana Bone Balla terdapat sebuah pintu gerbang dan benteng yang memanfaatkan struktur tanah yang tinggi dan Sungai Palakka sebagai tempat pertahanan. Penempatan benteng dan pintu gerbang di bagian barat selain difungsikan sebagai lokasi pertahanan pada bagian barat juga difungsikan sebagai batas wilayah mengingat wilayah pemukiman di Cenrana lebih dominan berada di bagian timur, selatan dan barat dari lokasi Istana Bone Balla.

Selain sumur, kompleks makam, pintu gerbang dan benteng juga ditemukan beberapa fragmen gerabah dan fragmen keramik asing. Fragmen tersebut ditemukan di bagian selatan lokasi Istana Bone Balla. Temuan ini membuktikan bahwa pada masa pemerintahan raja La Patau Matanna Tikka di bagian selatan pernah ada aktivitas yang mencerminkan pemukiman.

\section{d. Lokasi Sakral}

Lokasi sakral yang dimaksud, yaitu; Lokasi Masjid Tua Cenrana. Masjid Agung Cenrana merupakan masjid pertama di wilayah pemerintahan raja La Patau Matanna Tikka. Lokasi Masjid Agung Cenrana telah bergeser kurang lebih dua meter ke arah selatan dikarenakan terjadi pengikisan di tepi aliran sungai Cenrana. Masjid dibangun dekat aliran Sungai Cenrana disebabkan oleh sumber air yang dapat difungsikan sebagai persediaan air wudhu jika ingin melakukan ibadah.

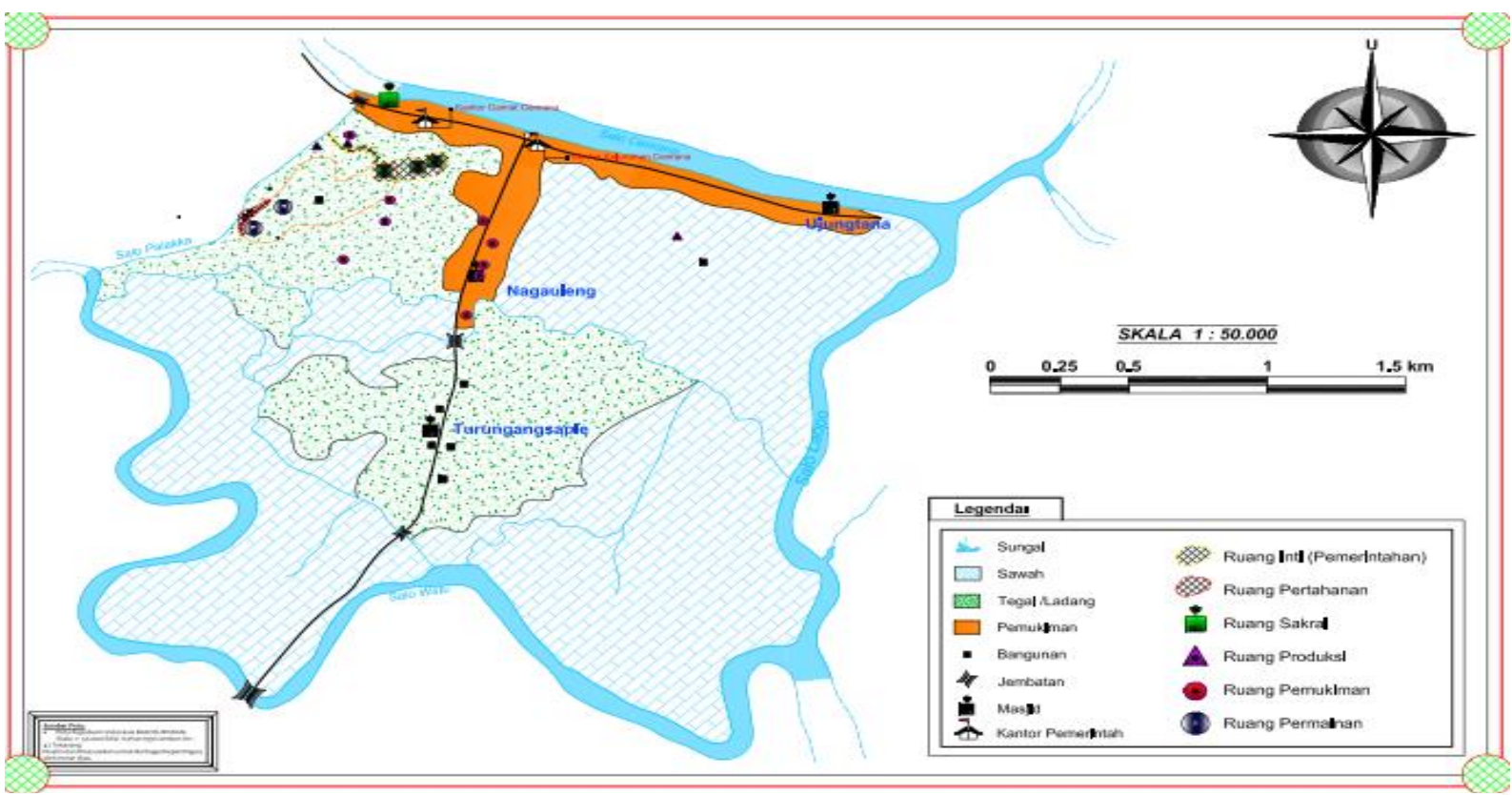

Gambar 3. Peta Pembagian Ruang Pemukiman Tepi Aliran Sungai Cenrana

(Sumber: Febi Wulandari, Tahun 2011) 
Keletakan masjid dekat dengan aliran sungai juga dimaksudkan sebagai tempat persinggahan, peristirahatan dan sosial masyarakat baik penduduk wilayah Cenrana atau pun para pendatang dari luar wilayah yang melewati Sungai Cenrana.

\section{PENUTUP}

Berdasarkan penggambaran yang telah dijelaskan di atas maka pemukiman Cenrana di sisi selatan tepi aliran Sungai Cenrana berada di garis sungai dengan pola sebaran linear mengikuti alur sungai dan mengarah dari arah timur ke arah barat. Pemukiman tersebut mengelompok dengan pola berderet dan mengikuti alur sungai dan jalan.

Selain itu, penataan ruang di wilayah Cenrana terbagi atas empat fungsi, yaitu: lokasi pemerintahan, lokasi produksi, lokasi pemukiman, dan lokasi sakral. Penentuan letak dari masing masing pembagian ruang merupakan wilayah yang strategis. Faktor utama yang mempengaruhi pembagian ruang tersebut yaitu ekonomi dan keadaan lingkungan yang mendukung, seperti; keadaan geografis, karakteristik lahan, sumberdaya alam dan aksesibilitas.

\section{UCAPAN TERIMA KASIH}

Terima kasih saya ucapkan kepada segenap pengajar Jurusan Arkeologi Universitas Hasanuddin karena telah membimbing tulisan ini dari skripsi. Terima kasih untuk teman-teman angkatan 2005 Arkeologi Universitas Hasanuddin yang telah membantu menyelesaikan penelitian ini.

\section{DAFTAR PUSTAKA}

Ali. Muhammad, 1984. Ruppa'na Bone (Perang Bone 1905). Watampone. 1989. Bone Selayang Pandang. Watampone: Depdikbud.

Ambary, H.M., 1998. Menemukan Peradaban: Jejak Arkeologis dan Historis. Jakarta: Logos Wacana Ilmu

Andaya. Leonard Y,dkk., 2004. Warisan Arung Palakka Sejarah Sulawesi Selatan Abad ke-17. Penerjemah. Sirimorok, Nurhadi. Makassar. Ininnawa.

Anonim, 2006. Bone Dalam Angka 2006. Watampone: Badan Pusat Statistik.

Anonim, 1999. Metode Penelitian Arkeologi. Jakarta: Pusat Penelitian Arkeologi Nasional.

Hasanuddin, 2001. "Pola Pemukiman dalam Arkeologi: Rekonstruksi Ekologi, Kebudayaan dan Struktur Masyarakat". Jurnal Walennae. Vol. IV. No 2. Hal 5-13. Makassar: Balai Arkeologi Makassar.

Makmur, 1997. Ragam Hias pada Kompleks Makam La Patau Matanna Tikka di Cenrana Kabupaten Bone Sulawesi Selatan. Skripsi. Arkeologi Universitas Hasanuddin. Makassar.

Mundardjito, 2002. Pertimbangan Ekologi: Penempatan Situs Masa Hindu-Budha Di Daerah Yogyakarta. Jakarta: Widatama Widya Sastra. 
Rady, Lina andi, 2007. Riwayat To Bone. Watampone: Departemen Pendidikan dan Kebudayaan.

Sarjiyanto, 2000. "Potensi Data arkeologi Situs Cenrana: Kajian Awal Bagi Studi Pemukiman". Walannae No. 4/III Balai Arkeologi Makassar. Makassar.

Sharer And Ashmore, 1980. Fundamentals of Archaeology. California: The Benyamin Publishing Company Inc. 
Lampiran Peta letak Kabupaten Bone di Sulawesi Selatan

(Sumber: Peta Bakosurtanal Skala 1:250.000, Tahun 1993)

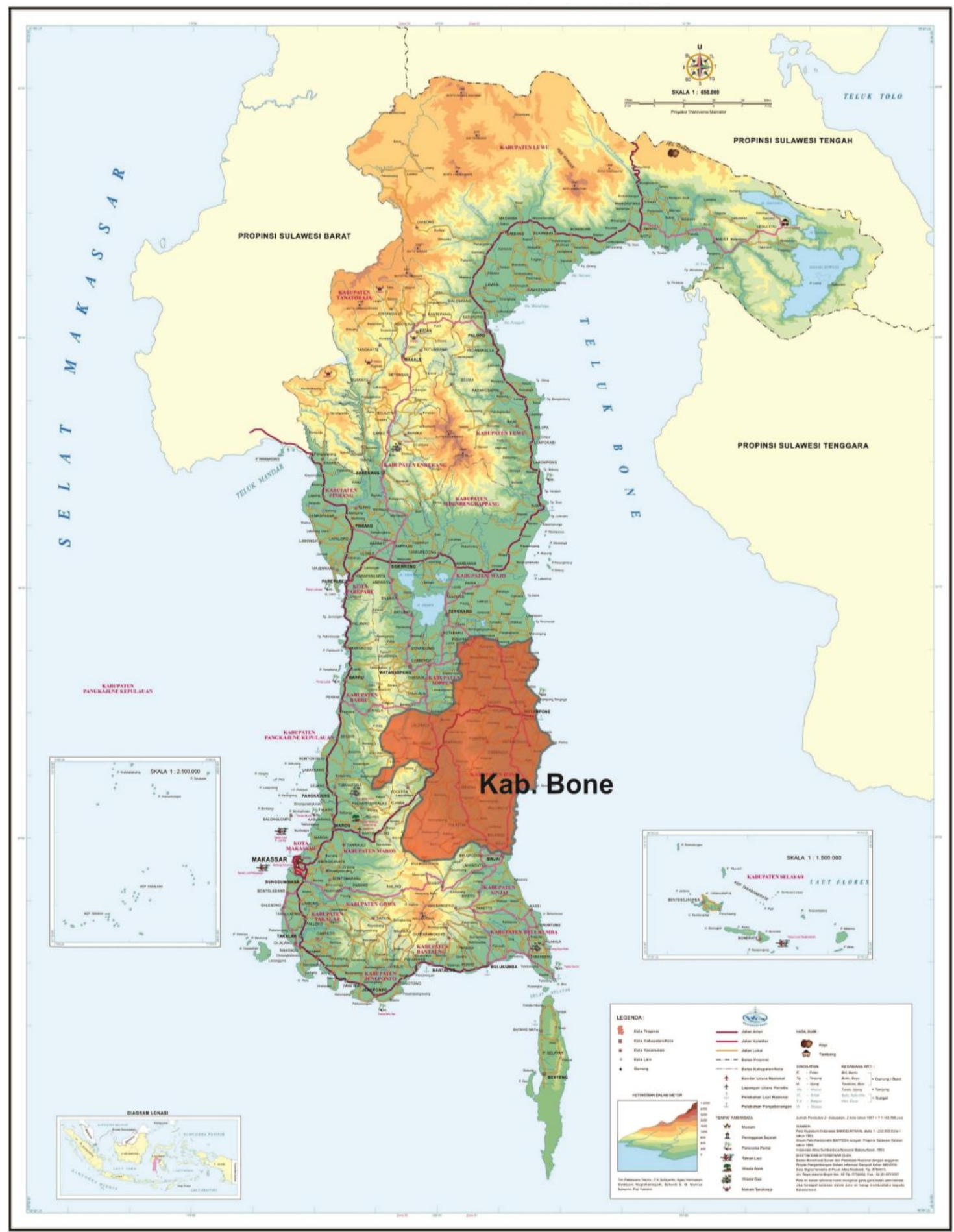

